\title{
TRANSACTIONAL POLITICAL PRACTICES IN THE ASYMMETRIC DECENTRALIZATION SYSTEM IN ACEH (10-YEAR ANALYSIS OF SPECIAL AUTONOMY FUND MANAGEMENT PERIOD 2008-2018)
}

\author{
Cut Maya Aprita Sari ${ }^{1^{*}}$, Muhammad Suhail Ghifari ${ }^{2}$, Kartini Aboo Talib @ Khalid ${ }^{3}$
}

${ }^{1 *}$ Institute of Ethnic Studies (KITA), Universiti Kebangsaan Malaysia and Departments of Political Science, Universitas Syiah Kuala, Aceh Indonesia; ${ }^{2}$ Departments of Political Science, Universitas Syiah Kuala, Aceh Indonesia; ${ }^{3}$ Institute of Ethnic Studies (KITA), Universiti Kebangsaan Malaysia.

Email: ${ }^{1 *}$ cutmayaapritasari@ unsyiah.ac.id, ${ }^{2}$ muhd.suhailghifari@gmail.com, ${ }^{3}$ k_khalid@ukm.edu.my

Article History: Received on $24^{\text {th }}$ March 2020, Revised on $16^{\text {th }}$ August 2020, Published on $19^{\text {th }}$ September 2020

\begin{abstract}
Purpose of the study: Within 10 years, the central government of Indonesia has granted the special autonomy fund to Aceh as a strategy to improve the welfare of Acehnese. Contrary, the special autonomy funds that cannot be implemented properly-affected to the poverty in Aceh-is not significantly decreased. This study aims to determine the failure of special autonomy funds to decrease poverty in Aceh.
\end{abstract}

Methodology: This research used descriptive qualitative methods by conducting the primary data through interviews, also secondary data through books, journals, newspapers, and other related sources. The analysis data is doing by using Transactional Political Theory.

Main Findings: The results of this study indicate that asymmetric decentralization can be seen from the weak Regional Economic Growth Rate and the slow improvement of the Quality of Human Development Index (HDI). Thus the failure was caused by two things, namely: the thick Political Content of The Local Political Elite and the Domination of Local Political Elite in the Management of Aceh's Special Autonomy Fund in the Compilation of Planning and Work Programs. The absence of control in the management of special autonomy funds is based on project performance without good planning, and the existence of interest-based planning in the management of special autonomy funds that based on populist activity programs following the wishes of politicians which have an impact on weak regional economic growth, slow index improvement of human development quality, high poverty rates, and high unemployment in Aceh.

Applications of this study: The finding of this study offered the evaluation systems for the government of Aceh to strengthen better local government governance, especially in increasing budget planning and implementation efficiency and strengthening regulations, and implementing an e-planning system to select program activities from the Aceh special autonomy fund.

Novelty/Originality of this study: Based on the literature review conducted, there were limited publications which are focusing on the failure of autonomy funds in Aceh. Therefore this research will enrich the publication that concerns the failure of managing special autonomy funds in Aceh.

Keywords: Political Transactional, Asymmetric Decentralization, Special Autonomy Funds, Poverty, Local Government, Acehnese.

\section{INTRODUCTION}

The concept of Decentralization was first introduced by Tarlton (1965) who divided the decentralization into two parts, symmetrical decentralization and asymmetric decentralization based on the level of conformity between the government and other units in a political system (Nasution, 2016). The symmetrical decentralization is built based on the assumption that all provinces have the same conditions and positions in the government. Whereas the asymmetric decentralization, it refers to the broadest autonomy that addressed at a part of a country. Generally, the section has featured in the legislative, executive, governance arrangements, greater access to fiscal resources, judicial power, or other features that distinguish it from other regions (Melbourne Forum On Constitution-Building, 2018; Amrizal et.al., 2015; Hadenius, 2003).

Also, decentralization becomes a popular strategy for the post-conflict area to manage the diversification in the multicultural state (Bakke, 2015; Brown, 2009). In this context, the constitution of the Republic of Indonesia places Aceh as an autonomous region because it has special and particularly local government units, related to the typical character of history and the struggle of the Acehnese people who have high resilience and struggle (Suharyo, 2016; Jalil et.al., 2010). The granting of special autonomy to Aceh has an impact on regional economic development, especially in terms of increasing government funds that are often referred to as special autonomy funds. Once the amount of special autonomy funds received by the Government of Aceh does not directly create Aceh much more advanced and more prosperous In fact, the special autonomy fund that has been received by Aceh has not been maximally utilized to improve the people's welfare (Ali, 2019; McGibbon, 2004; Aspinall \& Crouch, 2003). 
Based on the data conducted by BPS Aceh (2019), the poverty percentage in Aceh is not significantly decreased. There are only $16.89 \%$ in 2017 and $15.97 \%$ in 2018. The special autonomy fund received by the Government of Aceh so far has not been able to drive the pace of the region's economy to grow in an ideal manner.

The regional economic growth over the past eight years is still below 6.0\% on average, far from the 2012-2017 Aceh Medium-Term Development Plan (RPJMA) target (above 6.0\% to 8.0\%). Another point of concern is the slow improvement in the quality of human development between the blessings of an abundant budget. 2013 BPS data presents the Aceh Human Development Index (HDI) of 73.05\% or the second-lowest in Sumatra (Effendi, 2015).

The dominance of the political content of the local elite in planning and creating programs originated from special autonomy funds is reflected in the allocation of funds for populist programs according to the wishes and interests of politicians. The high political content is so dominant in the political aspects of Aceh compared to the economy thus making the concentration in the management of special autonomy funds (Aziz, 2018).

The temporary hypothesis of the problem occurs because: firstly, the weak local institutional capacity (Aspinall, 2009; ICG, 2007); Secondly, it is dominated by small-scale projects so that project work is not done through a tender process (Cahyono, 2018); Thirdly, the absence of criteria regarding the selection of activities and planning documents (Research Team at Syiah Kuala University, Malikulsaleh University, \& DSF World Bank Staff, 2011). Fourthly, the existence of former GAM combatants in Aceh's local politics which has become a new oligarchic power that not only controls politics but also controls Aceh's economic network (Aspinall, 2009; Barron et.al., 2019; Cahyono, 2018).

Overall, this study aims to explain the failure of special autonomy funds to decrease poverty in Aceh. Nevertheless, the offered hypothesis needs to be further proven through research conducted on "Transactional Political Practices in the Asymmetric Decentralization System in Aceh (Evaluation of the 10-Year Management of Special Autonomy Funds for the Period of 2008-2018)".

\section{LITERATURE REVIEW}

The term decentralization refers to the hierarchical relationship between the province and the districts which are the district's governments have a great power to manage public services and directly affected the quality of services (Takeshi, 2005). The literature which concerned about development offered that the decentralization is a strategy for improving service delivery (World Bank, 2001; McLean, 1999; Dilinger, 1994), resisting the corruption (Fjeldstad, 2004; Fisman 2002), enhancing the participation within society, reducing conflicts, and poverty (Olum, 2014; Braathen, 2008; Rondinelli, 2007; Crook, 2001; Hofman \& Kaiser, 2006; Kristiansen \& Pratikno, 2006; Litvack et.al., 1998).

On the other hand, decentralization may, therefore, a two-edge of swords (Brillantes Jr, 2004). Some failure on the implementation of decentralization could happen. This issue becomes venerable; therefore it has been widely studied by previous researchers. Decentralization, in some way, may cause macroeconomic instability, clientelism, service delivery failure, and bureaucratic swelling (Englebert \& Mungongo, 2016; Koelble \& Siddle, 2013; Iry, 2009; Falleti, 2004; Ryan, 2004). Also, Tommasi \& Weinschelbaum (2007), see that improving welfare is not possible if there is no accountability and responsibility of the government in managing autonomous funds. Correspondingly, decentralization requires the effectiveness of expenditure and the strength of income (Azfar et.al., 1999; Rodden, 2003; Jack, 2004; Rodriguez-Pose, 2009). Decentralization also needs a good institutional arrangement within government which rules power relationship between political institutions and society including democratic system, separations of powers, centerlocal relations, and federalism (Steffensen et al., 2004; Olum, 2014).

Aceh Province in 2007 in the definitive ceiling of Aceh's special autonomy in 2008-2018 and ceiling projection in 20082027, the total special autonomy fund for 20 years (2008-2027) reached Rp144.75 Trillion. Within 10 years the management of the special autonomy fund granted by the Central Government to the Government of Aceh had reached Rp64, 968 Trillion.

The size of the receipt of special autonomy funds in Aceh Province does not directly make society more advanced and more prosperous. The reality is that the special autonomy fund is more utilized for the benefit of a handful of individuals and groups in the ruling. The policies of the Government of Aceh that were born without a clear road map and projects that are not strategic (Cahyono, 2018).

Based on the literature review conducted, there were limited publications which are focusing on the failure of autonomy funds in Aceh. They analyze the failure of different causes. McGibbon (2004) in his article explained that the management of special autonomy funds in Aceh faced various problems. One of them is corruption. He found that special autonomy funds were widely used to finance a "fictive project" though actually, the project has never existed. Corruption is also common in local government agencies and departments such as mark-ups and embezzlement of funds. $\mathrm{He}$ also discovered that there were 22 projects with funds that didn't make sense. One of them occurred in the empowering women project with a total fund of $\$ 250,000$. This fact affected the failed autonomy fund to be maximally utilized to improve the Acehnese welfare rates. 
On the other hand, the World Bank (2006) found that autonomy funds in Aceh experiencing a system failure because of an irresponsible government. In this context, local governments performed transfer delays of special autonomy funds which affecting their cash flow and disrupting the implementation of development programs.

Planning and Development Agency of Banda Aceh City (BAPPEDA Aceh) stated that the utilization of special autonomy funds has brought significant improvements in several indicators in the education and health sectors. However, it has not been able to prove the impact of this special autonomy fund on economic growth and improving public welfare (Cahyono, 2018). The publications which concern about the failure of managing special autonomy funds in Aceh are slightly limited. Therefore, it was the main reason to conduct this research.

This research looks at the failure of the asymmetric decentralization can be seen from the weak Regional Economic Growth Rate and the slow improvement of the Quality of Human Development Index (HDI). Thus the failure was caused by two things, namely: the thick Political Content of The Local Political Elite and the Domination of Local Political Elite in the Management of Aceh's Special Autonomy Fund in the Compilation of Planning and Work Programs. It can be explained by using the asymmetrical decentralization theory and political transactional theory as below.

\section{METHODOLOGY}

The location of this research is in Aceh Province, thus the autonomy funds are given by the central government as consequences of the MoU Helsinki peace agreement 2005. This study uses a descriptive qualitative method. Data sources are based on primary data obtained through interviews, as well as secondary data, namely supporting data obtained from books, journals, newspapers, and other related sources. There were 8 informants in the study who were selected based on their ability to master data and information related to research, namely:

1. Drs. Sulaiman Abda, M.Si (Deputy Chair of the Aceh House of Representative (DPRA) 2014-2019);

2. Dr. Amrizal J. Prang, S.H., L.LM (The Head of Law Department in Aceh Regional Secretariat);

3. Erlanda Juliansyah Putra, S.H., M.H (The Expert Staff of the Indonesian House of Representatives);

4. Aryos Nivada, M.A (The Aceh Political Observer);

5. Askhalani (The Coordinator of Gerakan Anti Korupsi);

6. Dr. Fajran Zain, M.A (The Aceh Institute Researcher);

7. Dr. Sukriy Abdulah, S.E., M.Si.Ak (Lecturer of Faculty Economics and Business, Syiah Kuala University-Aceh and Observer of Aceh Special Autonomy);

8. Hafidh (The Coordinator of Public Policy Advocacy in Civil society of transparency Aceh community).

The results from these eight people are then classified according to their respective categories following the purpose of the study. The analysis data is doing by using Asymmetric Decentralization Theory and Transactional Political Theory (Bailey, 2001).

\section{FINDINGS}

The failure of the asymmetric decentralization in Aceh can be seen from the weak Regional Economic Growth Rate and the slow improvement of the Quality of Human Development Index (HDI). Thus the failure was caused by the practice of Political transactional within the Local Political Elite on Compilation of Planning and Work Programs in Managing Aceh's Special Autonomy Fund. Before discussing 'why the failure matters', we should know first about the model of special autonomy fund management period 2008-2018.

\section{A. Model of Special Autonomy Fund Management Period 2008-2018}

The management of special autonomy funds is allocated to finance various programs and strategic development activities that have an impact on the achievement of public welfare. In-Law Number 11 the Year 2006 concerning the Government of Aceh, it explains that the allocation of special autonomy funds is the Aceh Government's revenue which is intended to finance development, especially the development and maintenance of infrastructure, empowering the people's economy, alleviating poverty, and funding for education, social and health.

The allocation of funds for development funding on target in all sectors is expected to increase the strong thrust for Aceh in triggering the development of growth and prosperity. The management of the allocation of special autonomy funds for Aceh is then regulated in Aceh Qanun Number 2 of 2008 Article 10 paragraphs (1) and (2) concerning Procedures for the Allocation of Additional Oil and Gas Production Sharing Funds and the Use of Special Autonomy Funds. The total allocation of special autonomy funds received by the Aceh Government from 2008 to 2018 amounted to Rp64.968.761.095.480.

The welfare referring to asymmetric decentralization is very dependent on the form of regional financial management so that welfare objectives can be realized. Regional financial allocations must be used by applicable regulations in realizing 
public interests and must be supported by transparent, effective, and efficient financial management. Regional financial management also requires clear coordination at every level in the government.

The size of the receipt of special autonomy funds granted to the Government of Aceh, in the application of its implementation raises many problems. As for the problems that arise both in authority and regulation in the Aceh Qanun that is not completed, so that it impacts on the poor management of special autonomy funds. The asymmetric decentralization system policy has created various matters in regional autonomy. As an example of the problems that occur related to the authority of the management of special autonomy funds between the Government of Aceh and the Government of Regency / City, so that there are attractions of authority and interests between the two governments.

In the regulations governing the management of Aceh's special autonomy funds from 2008 to 2016, there is a model in the management of special autonomy funds which is carried out based on 3 (three) Qanun about the procedures for allocating and utilizing special autonomy funds designed by the Government of Aceh and approved by the Ministry of the Interior Country. This is as explained by Drs. H. Sulaiman Abda, M.Sc:

"In 10 years, the implementation of the Aceh special autonomy fund has reached Rp64, 968 trillion. In the first stage of management, the regulation set $60 \%$ for the allocation of districts/cities and $40 \%$ for the allocation of provinces. Furthermore, the province withdrew to be managed as a whole by the Provincial Government. Then the regulation changed again with the stipulation of 40\% of Regencies / Cities and 60\% of Provinces with a direct transfer mechanism."

There are 4 (four) regulatory models in the governance of special autonomy funds carried out since the special autonomy fund in Aceh came into force. Firstly, Aceh's Qanun Number 2 of 2008 concerning Procedures for the Allocation of Additional Oil and Gas Production Sharing Funds and the Use of Special Autonomy Funds lasted from 2008 to 2010, where the management of the special autonomy fund was centered on Aceh Province. The Provincial Government has the authority in the Budget User Authority (KPA) even though the program planning activities are carried out by the Regency / City Government. This Qanun was valid until 2009, whereby the implementation of projects using special autonomy funds is fully implemented by the Government of Aceh using the mechanism of the Aceh Revenue and Expenditure Budget (APBA) consisting of KPA and the Implementer Official of Technical Activities (PPTK) residing in the Aceh Apparatus Work Unit (SKPA).

In this case, the entire series of budget execution processes are started from the publication of budget implementation documents, procurement of goods and services, the process of supervising project implementation, and payments made to third parties fully carried out by the Provincial Government. The form of regulations stipulated in the Qanun for the management of special autonomy funds in their implementation raises many problems. The form of the problem is the high Excess of The Budget Use (SiLPA) and many of stalled project activities.

In 2010, the Government of Aceh implemented a mechanism for managing the special autonomy fund in the form of a "Ceiling". In this case, the Regency / City Government proposed a program of activities that used special autonomy funds. The amount of ceiling given to the Regency / City Government was arranged based on the matters in Aceh Governor Regulation Number 9 of 2017 in Article 8 Paragraph (6) explaining:

"Allocation ... divided by the balance: (a) 50\% (fifty percent) is allocated in equal portions, and (b) another 50\% (fifty percent) divided by considering several indicators such as 1. Population; 2. Area 3. Human Development Index (HDI); 4. Construction Expense Index (IKK); and 5. Other Balancing Indicators"

Secondly, it refers to demands involving the Regency / City Government in the management of special autonomy funds from 2010 to 2013. The Aceh Government's policy was created to provide the allocation of special autonomy funds to the Regency / City Government through the form of ceiling and not to use cash. The allocation of funds provided is $40 \%$ (forty percent) allocated to the Province and 60\% (sixty percent) is allocated to the Regency / City.

In this special autonomy fund management policy, the Regency / City Government is given the authority to propose a program of development activities, but in the KPA of the implementation and the implementation of project tender auctions are carried out entirely by the Provincial Government. The Regency / City Government, in this case, is only limited to being given authority over the proposed development activities program using special autonomy funds. However, implementations in the field are big problems, which the Regency / City Government has not been able to answer the problems that existed before. The problem refers to the authority, assets, and SiLPA which causes the management of special autonomy funds is not ideal.

Thirdly, Aceh Qanun Number 2 the Year 2013. Regency / City Governments demand the Provincial Government revise Aceh Qanun Number 2 the Year 2008, in which Regency / City Governments demand the Aceh Government change the "ceiling" mechanism to the "transfer" mechanism. So that a mutual agreement was created and the Provincial Government re-issued the Aceh Qanun Number 2 of 2013 concerning Amendments to the Aceh Qanun Number 2 of 2008 concerning How to Allocate Additional Oil and Gas Production Sharing Funds and Use of Special Autonomy Funds. Some changes in the Qanun can be seen in the allocation of funding, As explained by Dr. Amrizal J. Prang, S.H., L.LM: 
"When referring to the rules, the management authority can be found in the province but cannot be found in the regency/city. In 2013, the change in Qanun No.2 / 2013 which the allocation of these funds: $40 \%$ of the districts/cities and 60\% of the provinces. Changes in 2013 become the full authority of management in the province, $40 \%$ that is given but the province governing. Then it changed again to the No.1 / 2018 allocation of $40 \%$ of the Regency / City and 60\% of the Province and an additional allocation of $1 \%$ for the Provincial Capital."

In other words, Qanun No.2 / 2013 regulates that the allocation of funds is as much as 60\% (sixty percent) for the Provincial Government and $40 \%$ (forty percent) for the Regency / City Government using the direct transfer mechanism. Besides, the stipulated regulation also allocates a budget for programs and activities of development for the Capital of Aceh at most $1 \%$ (one percent).

In 2014, with the implementation of the direct transfer mechanism, the Regency / City Government had full authority in the management of special autonomy funds. In this case, the Regency / City Government has greater authority in receiving full budget allocations, including the remaining budget. So, as for decentralization, SiLPA in the district/city can be budgeted again in the following year by adjusting to the needs of each region. The job accountability mechanism at the Aceh Government in the SKPK becomes fully responsible for the implementation of the work until the follow-up inspection. Thus, it reduces the burden on SKPA towards the implementation of program activities in the District / City.

Under the concept of asymmetric where the presence of the Qanun has made the Regency / City Government increasingly add to the authority that it has in the management of special autonomy funds which focus on the distribution of the authority at various levels of government. It will be impacted by the Regency / City Government which can carry out more authority in the management of special autonomy funds to fulfill the needs of the community.

The form of the management of special autonomy funds carried out based on Qanun Number 2 of 2013 facilitates the implementation process, including guaranteeing to fund for programs/activities. The granting of special autonomy funds with a direct transfer mechanism does not provide guarantees in the timely implementation of the program, because, in essence, the transfers which are made is very determined rather than the timetable for APBA ratification and the timetable for submitting financial reports and progress reports at an advanced stage. A positive thing is found that the process of the activities program implementing will be faster because the process of the auction of the tender project is in the district/city.

Also, the positive impact of the implementation of the direct transfer mechanism of special autonomy funds can be seen from the report of studies conducted by the BAPPEDA Aceh related to the implementation and management of Aceh's special autonomy funds in 2015. The results of the study generally show that changes made to the qanun and other rules governing the governance of special autonomy funds have experienced positive improvements, although in the application in the field there are still various challenges in governance that still need special attention to continue to be improved.

Fourthly, Aceh Qanun Number 10 the Year 2016. In 2016 the Aceh Government again made a policy in managing Aceh's special autonomy fund which was centered $100 \%$ in the Province with the issuance of Aceh Qanun Number 10 the Year 2016 concerning the Second Amendment to Aceh Qanun Number 2 of 2008 Concerning Procedures Allocation of Additional Oil and Gas Revenue Sharing Funds and Special Autonomy Funds use. The amendment to the regulation was based on initiatives from the Aceh House of Representatives (DPRA).

The Qanun also revoked allocation rights of special autonomy funds for Aceh by $1 \%$ (one percent) allocated to the capital of the province. Therefore, the model of allocating the special autonomy fund back into the ceiling, which the Regency / City Government has the authority to propose activities program following the budget ceiling set by the Provincial Government that is technically fully managed by the Provincial Government.

The change in the Qanun has drawn protests from the Regents / Mayors in all Regencies / Cities that are members of the District / City Government Communication Forum (FKKA). In this case, the Regency / City Government concludes that the Provincial Government is not being fair to the Regency / City Government, because the amendment to the Qanun does not involve the Regency / City Government. The stipulation of Qanun carried out unilaterally has shown an unfair and transparent act and eliminates unilaterally the juridical rights of regencies/cities to receive directly part of the special autonomy fund regulated by the Central Government in Law Number 11 of 2006 Article 179 paragraph (1) and (2) letter C. Regarding Qanun number 2016, Askhalani explained:

"The change in the 2016 Qanun is due to political factors and the interests of the local political parties. The hope is there will be high fiscal discretion and can be obtained by the executive. The executive believes that take an important role in the mastering of the $40 \%$ projects allocated by the district/city. Previously the program activities in the project for regencies/cities were controlled by the Government of Aceh through the SKPA. In 2017, the Aceh Party has lost the regional election contestation and won by the PNA and Nova Iriansyah from the Demokrat, the $41 \%$ configuration of the Aceh Party urged a change in the qanun to return the management of the special autonomy fund to the District / City as much as 40\%. From this matter, it seems like that their authority was legitimate to rotate how to return special autonomy funds to the district/city because most of the Regents / Mayors are still controlled by the PA. Aceh Qanun that has changed 3 (three) times, 2 (two) changes from the original qanun " 
Furthermore, related to the 4 (four) regulatory models in the governance of special autonomy funds, Dr. Syukriy Abdullah, S.E., M.Si., Ak states that:

"In 2018 the Provincial Government wants all funds to be withdrawn by the province because the development undertaken by the Regency / City Government is considered to be unfavorable, even though until now there has been no research comparing the effective and efficient of the 3 (three) regulatory models. Whereas in 2019, all funds are withdrawn to the Province, the implementation will also be transferred to the Regional Government".

Regarding special autonomy funds that the amount of the funds received by Aceh province was failed to improve the welfare of the people of Aceh. This can be seen from two things, namely the weak of regional economic rate and The Slow Quality Improvement in Human Development Index as discussed below.

\title{
B. The Weak of The Regional Economic Growth Rate
}

The special autonomy fund received by the Government of Aceh so far has not been able to demonstrate its existence to encourage regional economic growth to grow in an ideal manner. The special autonomy fund from 2008 to 2018 increased significantly, but the pace of regional economic growth slowed. The thrust of economic growth is so weak in fact that regional economic growth over the past 8 (eight) years on average is still below 6.0\%, far from the 2012-2017 RPJMA target (above $6.0 \%$ to $8.0 \%$ ). Based on this phenomenon, Hafidh gave a response:

"There is an allegation from the people of Aceh that the special autonomy fund that should be for Aceh's recovery after the conflict was spent and enjoyed by certain circles. Therefore, the existence of the development that impacts on the economic growth of the community does not occur because the results cannot be enjoyed, neglected, and dysfunctional. This is because it is a necessity and designed without planning. "

Asymmetric decentralization is different from authority delegation. The difference lies in the special authority that is only given to certain regions. This special authority has become a strategy of the central government to prevent the desires of a regional government to separate from the motherland. Therefore the central government is trying to accommodate the local identity in the government system (Huda, 2014). For Aryos Nivada:

\begin{abstract}
"the special autonomy fund will have an economic impact ideally. There is an economic revival or economic empowerment and must be done. When the special autonomy ends and districts/cities are still sustained by special autonomy, then the potential for conflict will occur. Because there is no economic empowerment, unemployment rates are also high. The exist strategy that must be carried out by the government since 2017-2022 and this will be established and continued in the implementation of the program".
\end{abstract}

Not optimal economic growth causes high poverty and unemployment in Aceh and the highest in Sumatra. It becomes the main focus of the Government of Aceh today to be able to overcome poverty with a relatively short period with the end of the special autonomy fund in Aceh. But the imbalance in the individual income sector has not diminished in the last 10 years. The inequality is measured rather than the Gini Ratio (GR) which sees a decline in urban areas. However, there is a decrease in inequality between regions.

\section{The Slow Quality Improvement in Human Development Index}

The HDI of Aceh's condition is relatively not the worst in the Sumatra region, with an HDI value of $70.00 \%$ in 2016, slightly below the national HDI value of 70.18\%. The relatively good value of Aceh's HDI is thought to be caused by the relatively high value of Aceh's education indicators before the inclusion of the 2008 Special Autonomy Fund. Expectations Length of School (HLS) and Average Length of School (RLS) for Aceh in 2007 were already high (higher than HLS and national RLS), respectively reaches 12.90 years and 8.28 years. Then, after the Special Autonomy Fund, in 2017, the figure increased to 13.89 years and 8.86 years. (KOMPAK, 2018)

The presence of special autonomy funds has increased the RLS by $0.58 \%$ per year in the last 10 years. This enhancement is higher than the enhancement obtained by West Sumatra $0.46 \%$ per year and national $0.49 \%$ per year in the same period. Conversely, the enhancement in Aceh HLS 0.99\% per year in the last 10 years is still lower than West Sumatra $1.57 \%$ per year and nationally $1.43 \%$ per year. For this phenomenon, Erlanda Juliansyah Putra explained:

"Aceh's human development index is low because it is accompanied by human resources that are also not qualified yet. It is sufficient but not capable yet. Our limitations in language, access to information, and everything in education make human resources incapable. There are a lot of schools and even university graduates but they are not productive."

Therefore, it cannot be concluded that the Aceh Special Autonomy Fund, which is mostly allocated in the fields of education, health, and infrastructure which are strongly related to the variables forming HDI have succeeded in increasing Aceh's HDI. Especially after seeing an increase in Aceh HDI from 2015 to 2016, the amount of which is only 0.55 points lower than the increase in the HDI value of West Sumatra, Riau, and several other provinces in Sumatra (KOMPAK, 2018). 
The Human Development Index (HDI) of Aceh in 2017 reached 70.60\%, indirectly Aceh has been ranked 12th nationally. However, many sectors remain of particular concern such as health, education, and economic development. With Aceh's HDI rate of $70.60 \%$, it is still at the lowest position nationally at $70.81 \%$. To explain the development of the population by accessing the results of development in obtaining income, health, education, and so forth, it is only through the HDI in a region.

Referring to 2015 BPS data presented that the Aceh HDI was still 73.05\%. In 2013, the province with the highest achievements in human development in Sumatra was Riau Province 75.56\% while Aceh Province ranked ninth out of ten provinces in Sumatra with HDI 73.05\% (BPS Aceh, 2015). Based on these data, Fajran Zain says that:

"The Aceh government does not have an education program scenario and the people of Aceh do not know which programs are funded by the special and monumental autonomy fund. The human development index in Aceh is low. 30 years we have lived under conflict pressure, many schools are closed. This is contributing to the low human development index. Then the people of Aceh are waiting for the appearance of a new generation who will sit in the government after so many years of the peace agreement. "

Based on these data, we naturally wonder 'why did this happen?' The analysis shows that transactional politics is the cause of the failure of the management of special autonomy funds in Aceh. This transactional political practice is carried out by the local political elite on the compilation of planning and work programs in managing Aceh's special autonomy fund.

\section{DISCUSSION / ANALYSIS}

The failure of asymmetric decentralization in Aceh was caused by the practice of the political transactional within the Local Political Elite on Compilation of Planning and Work Programs in Managing Aceh's Special Autonomy Fund. Political transactional was one of political anthropology theory which is explained by Bailey (2001) in his book entitled Stratagems and Spoils: A Social Anthropology of Politics. Bailey explored that in social life, the values of harmony cannot always be realized. People's lives are full of deception, nepotism, and desire to use shortcuts in achieving his interest. The legal system established by the government cannot guarantee that people live according to the norm.

Bailey then states that in a society there are two forms of rules namely normative rules and pragmatic rules. Normative rules refer to ethical judgments of certain actions. These actions can be right or wrong. In contrast, pragmatic rules are a deviation from normative rules. Pragmatic rules explain that there are great gaps in society. People are too interested in the "system" even though we know that people live half their lives finding ways to beat the system. They seem to use the gaps in the norm to act as if they do not understand the norm. And the fact is, sometimes people do beat the system and are not punished. That's how the system changes (Bailey, 2001).

According to Bailey (2001), most of us are guided by self-interest and our thread between the norms for seeking the most advantageous route. In this context, each individual will do anything to achieve something that he wants even outside the norm. The situation as explained by Bailey is manifested in the management of special autonomy funds in Aceh. Transactional politics that occurred caused the failure of special autonomy funds in tackling the problem of poverty in Aceh.

Not ideally the implementation of special autonomy funds in Aceh can be seen from the "game" of the local political elite members of the House of Representatives in "processing and herding" aspiration funds, and also reflected in the powerlessness of the bureaucracy both within the BAPPEDA Aceh environment and in the circles of agencies in dealing with the intervention of politicians (Aziz, 2018).

The problem with managing special autonomy funds in Aceh is a large number of small-scale activity projects. Since the special autonomy fund was received by the Government of Aceh from the Central Government, there are so many projects that have been in the form of small packages ranging from Rp50-100 million, there are also Rp30 million. The existence of this small project package is a factor of intent to not be included in the tender process. The dominance of small projects is detrimental, first, most of the small packages are projects that are not strategic and do not have leverage for development and economic improvement.

This is parallel with the fact that the special autonomy fund has not been able to produce a strategic physical development project in Aceh. Second, the project which is divided into small groups has created a tendency to discriminate in project allocation only to the group, besides, to enrich the practice of project brokers considering that small-scale projects do not require a tender in determining partners (Cahyono, 2018).

Asymmetrical decentralization designs are a national policy choice to regulate some regions at the provincial level which for some reason has different designs of authority and distribution of resources. There are four provinces recorded, namely Aceh, DKI Jakarta, DI Yogyakarta, and Papua which are currently officially granted special status. The reasons underlying it are certainly different, but the spirit that is carried is the same, namely democratization and more equitable development so that eventually the desired welfare will be achieved (Bayo, 2012). 
The Government of Indonesia gives special autonomy to the Government of Aceh in terms of equitable development to equalize the Province of Aceh with other provinces in Indonesia with a good regional economic growth rate and increased HDI. It will still be a big problem in achieving this because there are small projects that are not strategic programs and do not have leverage on the economy and the existence of these small projects is a form of discrimination in the allocation of projects only to private interests or certain groups.

After the peace of the Aceh MoU in Helsinki, many groups of GAM combatants entered the business sectors. GAM combatants, especially among the elite, have developed themselves in the business sectors both individually and in groups. The former GAM combatants grew as part of the new middle class in Aceh. The existence of instructions from the central KPA for the formation of cooperatives in each region aims to support the business development so that many dozens of cooperatives spread throughout the district.

Ten years of the implementation of special autonomy funds received by the Government of Aceh reached Rp 64.968 Trillion is a form of one of the MoU Helsinki peace agreement by giving Aceh authority as a region with special autonomy status regulated in Law No. 11 of 2006. The form of special autonomy funds use that are set to fund 6 (six) programs and activities, including education, health, development and maintenance of infrastructure, poverty alleviation, empowerment of the people's economy and social and can be used to fund development in the framework of implementation special features of Aceh. However, the dynamics that occurred in the special autonomy fund of Rp64,968 Trillion received by the Government of Aceh today has not demonstrated its existence in the development of the 6 (six) priority programs.

The form of inhibiting regional economic growth, it is seen from the political side that the dramatic transformation of former GAM combatants at the leadership level as well as members who become entrepreneurs, seems to be seen as a form of the ongoing process of the peace consolidation in Aceh. The number of commanders and leaders of GAM combatants changed drastically from their assets. They are combatants who have become new wealthy people with the facilities they have obtained and are now becoming "successful" entrepreneurs.

The number of key figures in GAM combatants who turned professions into businessmen and also most of them became contractors working in the construction industry. Because the construction sector has become the main sector as the backbone of the local economy, which is characterized by a lot of project play without going through a tender process because of the development of collusion, in which the contractor is not only focused on business but also nuanced politics. (Aspinall, 2009). The reintegration process on political economy sectors for GAM combatants and they indicated the collusion through rent economic behavior. Former GAM combatants have turned themselves into construction contractors by utilizing their political and coercive resources as well as by collaborating with established contractors and building cooperation with state officials. Under the political transactional theory expressed by Bailey (2001), these contractors who came from GAM combatants were able to master several large-scale development projects in Aceh because of the nuances of collusion and nepotism with the Aceh government (which also originated from GAM combatants).

Furthermore, transactional politics is closely related to kinship factors. This is to facilitate the demand for and access to the use of money in politics. In this case, the revelation of Bailey (2001) is supported by Boissevain (1978) in his book entitled "Friends of Friends: Networks, Manipulators and Coalitions". He observed that the relationship between acquaintance and brotherhood became the foundation of transactional politics. The transactional politics are also carried out massively with political agreements to the parties, both businessmen and state officials. The Aceh case provides a striking illustration of the political influence and corruption at work in the construction sector in Indonesia, which began with an extraordinary "explosion" of development projects as a result of the reconstruction work following the tsunami in December 2004.

GAM entrepreneurs won contracts, not because of their experience, skills, and capacity in the construction sector. They won contracts because they had access to political power and the possibility of using violence (Cahyono, 2018; McGibbon, 2006). In other words, GAM won the contract because of the "Friends of Friends" as revealed by Boissevain (1978). The strong content of the local political elite can be seen from the "game" in "processing and leading" aspirational funds, as well as from the powerlessness of the bureaucracy within the BAPPEDA Aceh environment and the circles of agencies in dealing with the intervention of politicians. The aspiration fund has indirectly damaged all SKPA program planning. This happened because Board members intervened at the last second by forcing them to enter their programs without proper planning processes such as Conference on Development Planning.

So that it has an impact on the elimination of various programs from SKPA that have been prepared. For example in the RAPBA ceiling in 2016 reached Rp11.5 trillion when brought to the DPRA to be discussed the problem of attraction interests. This is because the board members have an allocation of Rp10 billion in aspirational funds.

Members of the Board also rejected the funds mentioned as aspiration funds, but they have another name, namely the "aspiration program" which will be included in various projects without the tender process of the aspirational funds whose impact will be a budget of Rp810 billion from SKPA that must be removed. This phenomenon shows that the 
form of authoritarianism still exists. Local political elites apply like "Suharto-Mini" or "Little King" who has a big contribution to the miss-allocation of special autonomy funds (Takeshi, 2006)

An indication of the game in the management of special autonomy funds through these aspirational funds causes a "drive" on the determination of a project and winning partners by the desires of the politicians. So, in the end, it is the game of the "fee" project that goes into the personal savings of members of the Board. (BPK RI Aceh Representative, 2013)

\section{CONCLUSION}

Through the discussion that has been discussed deeply and completely, the following conclusions can be drawn: The Revenue of the Aceh Government's Special Autonomy Fund in the 10 years of 2008/2018 has reached Rp64,968 trillion. These achievements do not make the community more advanced and prosperous. Within 10 years of managing Aceh's special autonomy fund, there were political factors in the changes in the regulations that were set, namely Qanun No.2 / 2008, Qanun No.2 / 2013, and Qanun No.10 / 2016 so that there were attraction interests in managing the special autonomy fund in Provincial and Regency / City Government level. Lack of supervision in the management of special autonomy funds is based on project play without good planning, and the existence of interest-based planning in the management of special autonomy funds can be seen in populist programs of activities according to the desires of politicians that have an impact on weak regional economic growth rates, the slow quality indexes of human development, high poverty rates, and high unemployment in Aceh.

The failure of special autonomy funds management in Aceh is caused by political transactional practices. This is carried out by the local political elite on the compilation of planning and work programs in managing Aceh's special autonomy fund and the dominance of local political elites in the management of Aceh's special autonomy fund in the preparation of plans and program activities is based on the dynamics of the budget political process in Aceh which is seen that there are indications of a process of barter interest in the discussion. The strong political content of the "game" in "processing and herding" aspirational funds that directly made all SKPA program plans damaged, thus it impacts the late APBA legalization. BAPPEDA Aceh cannot deal with intervention than politicians. The Conference on Development Planning carried out is not the only approach used for planning, because of the possibility of a planning process that goes through a political process.

\section{LIMITATION AND STUDY FORWARD}

The failure of special autonomy funds in overcoming poverty in Aceh was a complex problem. Such failure can be caused by many factors. The limitation of this research is only able to explain one factor, namely political transactional. It would be more interesting if the next study looked at other factors that might be the cause of the failure of the special autonomy fund in reducing poverty in Aceh. By using a different perspective, the study forward could be to produce more varied research findings.

\section{ACKNOWLEDGEMENT}

The authors thank Universitas Syiah Kuala and the research grant PP-KITA-2020 for making this research commendable.

\section{AUTHORS CONTRIBUTION}

Cut Maya Aprita Sari designed, lead the research, and constructing the main conceptual ideas; Muhammad Suhail Ghifari performed the data collection trough interview and analysis data; Kartini Aboo Talib @ Khalid contributed to developing the theoretical framework and proof outline. All authors discussed the findings and reviewed the final manuscript.

\section{REFERENCES}

1. Amrizal., Faisal, R., Budiman, G., Pendasteren, T. (2015). Asymmetric Decentralization Aceh; Governor Consultation and Consideration Context on Central Government Administrative Policy. IOSR Journal Of Humanities And Social Science (IOSR-JHSS) Volume 20, Issue 9, Ver. V (Sep. 2015), PP 01-10.

2. Ali, S. (2019). The Management Model of Aceh's Special Autonomy Fund. Jurnal Bina Praja: Journal of Home Affairs Governance. https://doi.org/10.21787/jbp.11.2019.159-170

3. Aspinall, E, and Crouch, H. (2003). The Aceh Peace Process: Why it Failed. Policy Studies 1: The East-West Center Washington.

4. Aspinall, E. (2009). Combatants to Contractors: The Political Economy of Peace in Aceh, in Indonesia. JSTOR. (87), 1-34.

5. Aziz, NLL. (2018). Politik Pengelolaan Dana Otonomi Khusus dan Istimewa. Jakarta: Yayasan Putra Obor Indonesia.

6. Azfar, O., Kähkönen, S., Lanyi, A., Meagher, P., and Rutherford, D. (1999). Decentralization, Governance And Public Services The Impact Of Institutional Arrangements. IRIS Center: University of Maryland, College Park.

7. Badan Pusat Statistik (BPS). (2015). Aceh Dalam Angka 2015. 
8. Badan Pusat Statistik Aceh (BPS). (2019). Indikator Kesejahteraan Masyarakat Aceh. BPS Provinsi Aceh.

9. Bailey, F. (2001). Stratagems And Spoils. New York: Routledge.

10. Bakke, K. M. (2015). Decentralization and intrastate struggles: Chechnya, Punjab, and Québec. Cambridge University Press. https://doi.org/10.1017/CB09781316146125

11. Barron, P., Rahmant, E., Nugroho, K. (2019). The Contested Corners Of Asia: Subnational Conflict and International Development Assistance. https://www.asiafoundation.org/resources/pdfs/AcehC aseStudyFullReport.pdf

12. Bayo, LN. (2012). Laporan Akhir Desentralisasi Asimetris yang Menyejahterakan: Aceh dan Papua. JPP FISIPOL : Universitas Gadjah Mada.

13. Boissevain, J. (1978). Friends of Friends: Networks, Manipulators and Coalitions. NewYork: St. Martin's Press.

14. BPK RI. (2013). Laporan Hasil Pemeriksaan Kinerja atas Pengelolaan dan Pertanggungjawaban Dana Otonomi Khusus TA 2008-2012 pada Bidang Pembangunan Jalan dan Jembatan di Dinas Bina Marga dan Cipta Karya Aceh dan Instansi Terkait di Provinsi Aceh. Banda Aceh: BPK RI Perwakilan Aceh.

15. Braathen, E. (2008). Decentralization and Poverty Reduction, A review of the linkages in Tanzania and international literature. Norad Report 22b/2008 Discussion, Norwegian Agency for Development Cooperation. http://www.norad.no/items/14184/38/2084279701/Decentralisation\%20and\%20Poverty\%20Reduction.pdf

16. Brillantes Jr., Alex. (2004). Decentralization Imperatives, Lessons from Some Asian Countries. Journal of International Cooperation Studies, Vo. 12 No. 1, August.

17. Brown, G. K. (2009). Federalism, regional autonomy and conflict: Introduction and overview. Ethnopolitics, 8(1), 1-4. https://doi.org/10.1080/17449050902738887

18. Cahyono, H. (2018). Politik Pengelolaan Dana Otonomi Khusus dan Istimewa. Yayasan Putra Obor Indonesia. Jakarta.

19. Crook, R., Sverrisson, A. (2001). Decentralization and Poverty Alleviation in Developing Countries: A Comparative Analysis, or Is West Bengal Unique? Institute of Development Studies: Brighton.

20. Dillinger, W. (1994). Decentralization and Its Implications for Urban Service Delivery. Urban Management Program Discussion Paper 16 (Washington, DC: World Bank), cited in Richard C. Crook and James Manor, Democracy and Decentralization in South-East Asia and West Africa: Participation, Accountability, and Performance (Cambridge: Cambridge University Press, 1998). https://doi.org/10.1596/0-8213-2792-5

21. Effendi, R. (2015). Dana Otsus vs Kesejahteraan. Serambinews.com. http://aceh.tribunnews.com/2015/05/21/dana-otsus-vs-kesejahteraan

22. Englebert, P., \& Mungongo, E.K. (2016). Misguided and Misdiagnosed: The Failure of Decentralization Reforms in the DR Congo. African Studies Review 59(1), 5-32. https://doi.org/10.1017/asr.2016.5

23. Falleti, TG. (2004). A Sequential Theory of Decentralization and Its Effects on the Intergovernmental Balance of Power: Latin American Cases In Comparative Perspective. Working Paper \#314, July. http://www.ciaonet.org/wps/fat01/fat01.pdf.

24. Fjeldstad, OH. (2004). Decentralisation and Corruption: A Review of the Literature. Chr.Michelson Institute: Bergen.

25. Fisman, R., Gatti, R. (2002). Decentralization and corruption: evidence across countries. Journal of Public Economics 83(3): 325-345. https://doi.org/10.1016/50047-2727(00)00158-4

26. Hadenius, A. (2003). Decentralization and democratic governance experiences from India, Bolivia and South Africa. Sweden: Almqvist \& Wiksell International.

27. Huda, N. (2014). Desentralisasi Asimetris Dalam NKRI Kajian Terhadap Daerah Istimewa, Daerah Khusus dan Otonomi Khusus. Nusa Media. Bandung

28. Hofman, B., and Kaiser, K. (2006). Decentralization, democratic transition, and local governance in Indonesia. In P. Bardhan \& D. Mookherjee (Eds.), Decentralization and local governance in developing countries: a comparative perspective (pp. 81-124). Cambridge, Mass. and London: MIT Press.

29. ICG. (2007). Aceh: Post-Conflict Compilations. Jakarta: International Crisis Group.

30. Iry, A.G. (2009). Dari Papua Meneropong Indonesia. Jakarta: PT. Gramedia Widiasarana Indonesia.

31. Jack, W. (2004). The organization of public service provision. Journal of Public Economic Theory 6(3), 409425. https://doi.org/10.1111/j.1467-9779.2004.00172.x

32. Jalil, H., Yani, T.A., Yoesoef, M.D. (2006). Implementasi Otonomi Khusus Di Provinsi Aceh Berdasarkan Undang-Undang Nomor 11 Tahun 2006. KANUN No. 51 Edisi Agustus 2010.

33. KOMPAK. (2018). Evaluasi Pemanfaatan Dana Otonomi Khusus Aceh 2008-2017. Jakarta.

34. Koelble, TA and Siddle, A. 2013. Why Decentralization in South Africa Has Failed. Governance: An International Journal of Policy, Administration, and Institutions. Vol.26, No.3. July (pp.343-346). https://doi.org/10.1111/gove.12022

35. Kristiansen, S., and Pratikno. (2006). Decentralising education in Indonesia. International Journal of Educational Development. 26(5), 513-531. https://doi.org/10.1016/.ijedudev.2005.12.003

36. Litvack, J., Ahmad, J., Bird, R. (1998). Rethinking Decentralization in Developing Countries. Washington, D.C: The World Bank. https://doi.org/10.1596/0-8213-4350-5 
37. McGibbon, R. (2006). Local Leadership and The Aceh Conflict, in Anthony Reid, ed. 2006, Verandah Of Violence: The Background to the Aceh Problem. Singapore University Press. Pp. 315-59.

38. McGibbon, R. (2004). Secessionist Challenges in Aceh and Papua: Is Special Autonomy the Solution. Policy Studies 10.Washington: The East-West Center.

39. McLean, K, and Elizabeth, K. (1999). Decentralization of the Education Sector in World Bank Institute (ed.), Decentralization Briefing Notes. WBI Working Papers. Available online http://www.worldbank.org/wbi/publications/wbi37142.pdf

40. Melbourne Forum on Constitution-Building. (2018). Asymmetric Territorial Arrangements in Decentralized Systems. Constitutional INSIGHT No.3 October 2018. The University Of Melbourne. https://www.idea.int/sites/default/files/publications/asymmetric-territorial-arrangements-in-decentralizedsystems.pdf

41. Nasution, I. (2016). The Challenge of Decentralization in Indonesia Symmetrical and Asymmetrical Debate. International Journal of Social Science and Humanity, 6(9), 691-697. https://doi.org/10.18178/ijssh.2016.6.9.734

42. Olum, Y. (2014). Decentralisation in Developing Countries: Preconditions for Successful Implementation. Commonwealth Journal of Local Governance (CJLG) 2014, 0, 4061. https://doi.org/10.5130/cilg.v0i0.4061

43. Research Team at Syiah Kuala University, Malikulsaleh University, \& DSF World Bank Staff (Decentralization Support Facility). (2011). Kajian Pengelolaan dan Pemanfaatan Dana Otsus Aceh. Jakarta: DSF.

44. Rodden, J. (2003). Reviving Leviathan: fiscal federalism and the growth of government. International Organization 57, 695-730. https://doi.org/10.1017//50020818303574021

45. Rodriguez-Pose, A., Tijmstra, S., Bwire, A., (2009). Fiscal decentralization, efficiency, and growth. Environment and Planning A 41, 2041-2062. https://doi.org/10.1068/a4087

46. Rondinelli, D. (2007). Parallel and Partnership Approaches to Decentralized Governance: Experience in Weak States. In Cheema G. \& Rondinelli D. (Eds.), Decentralizing Governance: Emerging Concepts and Practices (pp. 21-42). Brookings Institution Press.

47. Ryan, Jeffrey J. (2004). Decentralization and Democratic Instability: The Case of Costa Rica. Public Administration Review. Vol. 64, Issue 1 - January. https://doi.org/10.1111/i.1540-6210.2004.00348.x

48. Steffensen, J., Tidemand, P., Naitore, H., Ssewankambo, E., and Mwaipopo, E. (2004). Final Synthesis Report: A Comparative Analysis of Decentralisation in Kenya, Tanzania, and Uganda (NCG), August.

49. Suharyo, Suharyo. (2016). Otonomi Khusus di Papua dan Aceh Sebagai Perwujudan Implementasi Peranan Hukum dalam Kesejahteraan Masyarakat. Jurnal RechtsVinding. 5 (3): 323-337. https://rechtsvinding.bphn.go.id/artikel/ART\%203\%20JRV\%205.3\%20WATERMARK.pdf

50. Takeshi, I. (2006), The Dynamics of Local Governance Reform in Decentralizing Indonesia: Participatory Planning and Village Empowerment in Bandung, West Java. Journal of Asian and African Area Studies. 5 (2): $137-8$.

51. Tarlton, C. (1965). Symmetry and Asymmetry as Elements of Federalism: A Theoretical Speculation. The Journal of Politics, Vol. 27, No. 4 (Nov. 1965), pp. 861-874.The University of Chicago Press. https://doi.org/10.2307/2128123

52. Tommasi, M., Weinschelbaum, F. (2007). Centralization vs. decentralization: a principal-agent analysis. Journal of Public Economic Theory 9(2), 369-389. https://doi.org/10.1111/1.1467-9779.2007.00311.x

53. World Bank. (2006). Aceh Public Expenditure Analysis Spending For Construction And Poverty Reduction. http://siteresources.worldbank.org/INTINDONESIA/Resources/Publication/280016-1152870963030 IAPEA.pdf

54. World Bank. (2001). Decentralization and Governance: Does Decentralization Improve Public Service Delivery? in PremNotes No. 55. http://www1.worldbank.org/prem/PREMNotes/premnote55.pdf 